Inventa : Jurnal Pendidikan Guru Sekolah Dasar

http://jurnal.unipasby.ac.id/index.php/jurnal_inventa

\title{
ANALISIS KESULITAN SISWA DALAM PROSES PEMECAHAN MASALAH SOAL CERITA BILANGAN PECAHAN KELAS V SD NEGERI KARANGTEMPEL SEMARANG
}

\author{
Julia Intan Permatasari' ${ }^{1)}$, Husni Wakhyudin ${ }^{2)}$, Fajar Cahyadi ${ }^{3)}$ \\ 1),2),3) Universitas PGRI Semarang
}

Corresponding author E-mail: juliaintan532@gmail.com

\section{Kata Kunci: \\ Pemecahan Masalah,} Operasi Hitung Pecahan

\section{Abstrak}

Fokus penelitian ini adalah kesulitan belajar apa yang dialami oleh siswa kelas V SD Negeri Karang Tempel dilihat dari kemampuan pemecahan masalah matematika materi Bilangan Pecahan serta faktor apakah yang mempengaruhi kesulitan belajar siswa kelas V pemecahan masalah matematika SD Negeri KarangTempel. Tujuan penelitian ini adalah untuk Mengetahui adanya kesulitan belajar yang dialami oleh siswa SD Negeri KarangTempel dilihat pada kemampuan pemecahan masalah matematika materi Bilangan Pecahan serta mengetahui faktor yang mempengaruhi kemampuan pemecahan masalah matematika materi pecahan materi Bilangan Pecahan siswa kelas V SD Negeri KarangTempel Semarang. Penelitian menggunakan metode kualitatif dengan pendekatan deskriptif. Pengumpulan data dalam penelitian dilakukan dengan cara observasi, angket, soal, wawancara dan dokumentasi. Wawancara dilakukan dengan guru kelas $\mathrm{V}$ dan siswa kelas V SD Negeri KarangTempel Semarang.Berdasarkan hasil penelitian di SD Negeri KarangTempel, terdapat kesulitan belajar pada materi Bilangan Pecahan dilihat dari kemampuan pemecahan masalah matematika.

\section{Abstract}

\section{Keyword:}

Troubleshooting,

Fraction Count

Operation

The focus of this research is on what learning difficulties are experienced by fifth grade students of SD Negeri KarangTempel seen from the ability to solve math problems with Fractional Numbers and what factors affect the learning difficulties of fifth grade students in solving math problems at SD Negeri KarangTempel. The purpose of this study was to determine the existence of learning difficulties experienced by students of SD Negeri KarangTempel seen in the ability to solve mathematical problems in the material of Fractional Numbers and to find out the factors that affect the ability to solve mathematical problems in the matter of fractions in the material of Fractional Numbers of fifth grade students of SD Negeri KarangTempel Semarang. The study used qualitative methods with a descriptive approach. Data collection in the study was carried out by means of observation, questionnaires, questions, interviews and documentation. Interviews were conducted with fifth grade teachers and fifth grade students at KarangTempel State Elementary School, Semarang..

\section{Pendahuluan}

Pendidikan adalah investasi sumber daya manusia jangka panjang yang mempunyai nilai strategis bagi kelangsungan peradaban

manusia di dunia. Begitu juga dengan Indonesia yang menempatkan variabel 
pendidikan sebagai sesuatu yang penting dan utama dalam konteks pembangunan bangsa dan negara. Pendidikan adalah suatu dasar yang mengawali segala macam bidang di Indonesia. Oleh karena itu seluruh warga negara Indonesia berhak mendapatkan pendidikan. Pendidikan di Indonesia pada umumnya mengarah pada pendidikan Nasional yang berlandaskan pada Pancasila dan Undang- Undang Dasar Negara Republik Indonesia Tahun 1945.

Pada Undang-Undang Nomor 20 tahun 2003 tentang Sistem Pendidikan Nasional, Pasal 3, tujuan pendidikan nasional adalah mengembangkan potensi peserta didik agar menjadi manusia yang beriman dan bertakwa kepada Tuhan Yang Maha Esa, berakhlak mulia, sehat, berilmu, cakap, kreatif, mandiri, dan menjadi warga negara yang demokratis serta bertanggung jawab. Pada jenjang sekolah dasar pendidikan bertujuan untuk memberi bekal kepada siswa untuk hidup bermasyarakat dan dapat memperoleh perkembangan sosial dan kemampuan individu secara optimal. Sekolah Dasar merupakan sekolah pertama yang mendapatkan tumpuan besar dan harapan untuk dapat membekali konsep dasar bagi anak. Oleh karena itu, hendaknya ada korelasi antara harapan masyarakat dan tujuan pendidikan dasar.

Kelompok mata pelajaran yang dipelajari di sekolah dasar berdasarkan Peraturan Pemerintah (PP) Nomor 19 Tahun
2005 tentang Standar Nasional Pendidikan, Pasal 6 Ayat (1) adalah bahwa kurikulum untuk jenis pendidikan umum, kejuruan, dan khusus pada jenjang pendidikan dasar dan menengah terdiri atas: 1) agama dan akhlak mulia; 2) kewarganegaraan dan kepribadian; 3) ilmu pengetahuan dan teknologi; 4) estetika; 5) jasmani, olah raga, dan kesehatan.

Kelas V sekolah dasar termasuk kelas tinggi yang harus mempelajari lima kelompok mata pelajaran pada kurikulum tersebut di atas. Matematika merupakan pelajaran yang sangat penting dalam menunjang kehidupan manusia. Matematika sebagai pondasi untuk membangun penalaran perlu diberikan pada semua siswa di semua tingkatan. Pemecahan masalah merupakan salah satu kemampuan yang harus dikuasai siswa setelah belajar matematika. Kemampuan ini sangat diperlukan siswa, terkait dengan kebutuhan siswa untuk memecahkan masalah yang dihadapinya dalam kehidupan sehari-hari dan mampu mengembangkan diri mereka sendiri. Oleh sebab itu, kemampuan pemecahan masalah perlu mendapatkan perhatian khusus dalam proses pembelajaran matematika dari jenjang pendidikan formal paling dasar, yaitu di SD.

Salah satu materi pelajaran matematika di SD dan menjadi fokus dalam penelitian ini adalah pecahan. Pecahan merupakan salah satu materi penting yang harus dikuasai oleh siswa, hal ini dikarenakan materi pecahan 
berkaitan dengan materi lain seperti desimal, perbandingan dan skala serta pengukuran. Namun kenyataanya, siswa SD masih kesulitan dalam mempelajari materi pecahan. Pada saat wawancara dengan guru kelas V Anis Iskanah, S.Pd beliau mengatakan bahwa "sebagian besar siswa mengalami kendala dalam proses pembelajaran matematika yaitu kesulitan memahami konsep yang dipelajari pada materi yang disampaikan oleh guru, sehingga hasil belajar siswa tidak memuaskan karena kebanyakan dari mereka tidak memperhatikan saat guru menerangkan pelajaran dan kurang aktif dalam pembelajaran.

Melalui paparan yang sudah di jelaskan di atas akan dilakukan penelitian dengan judul “ Analisis Kesulitan Siswa Dalam Proses Pemecahan Masalah Soal Cerita Bilangan Pecahan Kelas V SD Negeri KarangTempel Semarang.

\section{Metode}

Jenis penelitian ini adalah penelitian deskriptif dengan pendekatan kualitatif. Penelitian ini bertujuan untuk mendeskripsikan kesulitan siswa dalam menyelesaikan soal pemahaman konsep dan soal cerita pada materi operasi hitung pecahan. Langkah pertama dalam penelitian ini adalah menentukan lokasi penelitian, berkoordinasi dengan guru matematika di tempat penelitian untuk memilih subyek penelitian serta menentukan jadwal penelitian, dan menyiapkan instrumen yang diperlukan untuk kegiatan penelitian.

Penelitian ini dilaksanakan di SD Negeri KarangTempel Semarang. Subyek dari penelitian ini adalah siswa kelas $\mathrm{V}$ yang berjumlah 13 siswa terdiri dari 9 perempuan dan 4 laki-laki. Adapun yang diteliti adalah proses kegiatan pembelajaran siswa pada mata pelajaran matematika dan hasil tes yang di lakukan peneliti. Sehingga peneliti dapat mengetahui kesulitan siswa dalam memecahkan masalah matematika pada materi operasi hitung pecahan.

Pengumpulan data dilakukan untuk memperoleh informasi yang dibutuhkan dalam rangka mencapai tujuan penelitian. Data yang dikumpulkan dari setiap variabel ditentukan oleh definisi operasional variabel yang bersangkutan. Dalam penelitian ini prosedur pengumpulan data ada beberapa macam. Yang pertama observasi, adapun pada metode ini peneliti menggunakan observasi tidak terstruktur yaitu ialah pengamatan yang dilakukan tanpa menggunakan pedoman observasi, sehingga peneliti mengembangkan pengamatannya berdasarkan perkembangan yang terjadi di lapangan. Yang kedua wawancara, secara sederhana dapat dikatakan bahwa wawancara (interview) adalah suatu kejadian atau suatu proses interaksi antara pewawancara (interviewer) dan sumber informasi atau orang yang di 
wawancarai (interviewee) melalui komunikasi langsung (yusuf, 2014). Dalam penelitian ini metode interview atau wawancara digunakan untuk menggali data tentang kesulitan siswa dalam materi operasi hitung pecahan.

\section{Hasil dan Pembahasan}

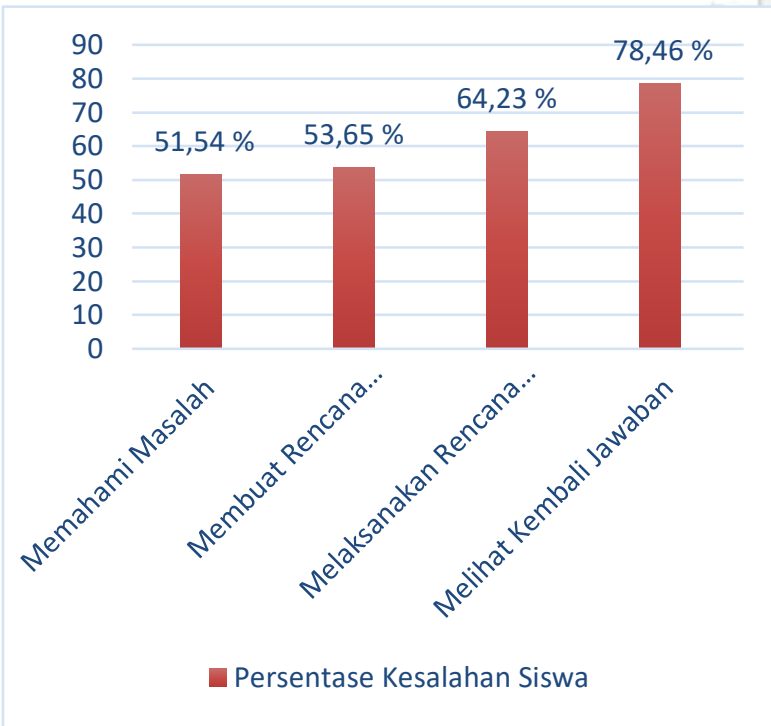

Gambar 1. Bagan Hasil Presentase Kesalahan Siswa dalam Memecahkan Masalah Matematika Materi Operasi Hitung Pecahan

Berdasarkan gambar 1. menunjukkan bahwa persentase kesalahan siswa dalam memecahkan masalah matematika materi operasi hitung pecahan pada kelas V SD Negeri KarangTempel Semarang diperoleh hasil yaitu dalam menggunakan aspek langkah-langkah pemecahan masalah, sebanyak 51,54\% siswa belum mampu memahami masalah dalam menentukan hubungan fakta-fakta dan membuat formulasi pertanyaan. Hasil persentase tersebut hampir seimbang dengan aspek membuat rencana pemecahan masalah, persentase menunjukkan bahwa sebanyak 53,65\% siswa masih melakukan kesalahan dalam membuat rencana pemecahan masalah untuk menentukan strategi dalam memecahkan masalah. Selanjutnya dalam melaksanakan rencana pemecahan masalah sebanyak $64,23 \%$ siswa masih melakukan kesalahan dalam menentukan strategi pemecahan masalah yang benar.

Sebagian besar siswa masih keliru dalam menyamakan penyebut yang berbeda pada operasi hitung pecahan. Sedangkan sebesar $78,46 \%$ siswa melakukan kesalahan dalam aspek melihat (mengecek) kembali jawaban. Sebagian besar siswa lupa tidak menuliskan kesimpulan dan satuan dari hasil pekerjaannya. Dari hasil presentase kesalahan siswa dalam memecahkan masalah matematika menunjukkan bahwa persentase kesalahan tertinggi terdapat dalam melihat (mengecek) kembali jawabannya. Sedangkan untuk persentase terendah yaitu dalam memahami masalah.

Menjawab rumusan masalah yang kedua, mengenai kesulitan belajar dalam memecahkan masalah matematika kelas V SD Negeri KarangTempel Semarang dalam materi operasi hitung pecahan, peneliti menggunakan hasil lembar angket siswa, lembar wawancara siswa, dan lembar wawancara guru yang dilakukan secara mendalam.

Peneliti kemudian menganalisis hasil lembar angket siswa secara keseluruhan untuk mengetahui kesulitan belajar yang dialami 
oleh setiap siswa dan faktor yang mempengaruhi kesulitan belajar siswa. Dari data angket yang sudah terkumpul diperoleh berbagai jawaban dan sebagian besar siswa menuliskan alasan dari jawaban tersebut.

Dari hasil lembar angket siswa menunjukkan bahwa walaupun siswa belum mampu menyamakan penyebut yang berbeda pada operasi hitung pecahan tetapi sebanyak $65 \%$ siswa sudah menggunakan cara penyelesaian soal cerita dengan langkahlangkah penyelesaian masalah soal cerita matematika seperti diketahui, ditanya, dan dijawab dengan benar.

Dari hasil wawancara siswa yang dilakukan secara mendalam oleh 5 sampel yang dapat dilihat pada lampiran 10 menunjukkan bahwa siswa yang mengalami kesulitan belajar dengan hasil belajar terendah yaitu siswa masih menganggap soal cerita sulit karena beberapa faktor yang mempengaruhi yaitu siswa tidak paham ketika guru menjelaskan materi pelajaran, terdapat kesulitan dalam memahami kalimat soal cerita, dan siswa sering tidak belajar ketika dirumah, sedangkan disekolah siswa selalu ramai sendiri dikelas sehingga tidak mendengarkan ketika guru menjelaskan materi pelajaran.

Berdasarkan data hasil lembar angket, lembar wawancara siswa dan wawancara guru menunjukkan bahwa kesulitan belajar siswa dalam memecahkan masalah matematika pada operasi hitung pecahan kelas V SD
Negeri KarangTempel Semarang siswa masih mengalami kesulitan belajar pada saat mengerjakan soal cerita matematika operasi hitung pecahan, sehingga hasil nilai yang didapatkan belum memenuhi Kriteria Ketuntasan Minimal (KKM).

Berdasarkan hasil analisis data yang sudah dilakukan dapat diketahui bahwa, siswa mengalami kesulitan dalam memahami masalah pada soal cerita, hal ini sesuai dengan penelitian (Utari, dkk, 2019: 546) yaitu menjelaskan bahwa kesulitan yang sering dialami siswa sebagian besar pada saat mengerjakan soal cerita karena siswa kurang mampu memahami maksud soal dan kebingungan saat menetukan operasi hitung yang akan digunakan. Selain itu siswa juga kesulitan dalam menyelesaikan soal cerita dengan langkah-langkah penyelesaian soal matematika secara tepat, Siswa kesulitan dalam melakukan penghitungan ketika menyelesaikan soal cerita seperti siswa tidak teliti ketika sedang menghitung angka.

\section{Kesimpulan}

Berdasarkan hasil analisis data dari penelitian yang sudah dilakukan maka diperoleh kesimpulan bahwa: Kesalahan siswa dalam memecahkan masalah matematika operasi hitung pecahan kelas V SD Negeri KarangTempel Semarang sebanyak 51,54\% siswa belum mampu memahami masalah dalam menentukan hubungan fakta-fakta dan 
membuat formulasi pertanyaan. 53,65\% siswa masih melakukan kesalahan dalam membuat rencana pemevahan masalah untuk menentukan strategi dalam memecahkan masalah.

Kesulitan belajar siswa dalam memecahkan masalah matematika kelas V SD Negeri KarangTempel Semarang, dari hasil angket siswa, wawancara guru, wawancara siswa menunjukkan bahwa siswa masih kesulitan dalam menyelesaikan soal cerita matematika karena sebagian besar siswa menganggap bahwa soal matematika itu sulit, sering menyebabkan pusing ketika sedang mengerjakan soal, dan siswa kurang paham ketika guru menjelaskan materi pembelajaran.

Berdasarkan simpulan, maka dalam kesempatan ini peneliti ingin menyampaikan saran sebagai berikut:

1. Sekolah hendaknya lebih menekankan penerapan materi bilangan pecahan pada soal cerita, sehingga perilaku tersebut lebih baik dari sebelumnya.

2. Penerapan materi bilangan pecahan dan pecahan campuran perlu dipertahankan dan ditingkatkan lagi dalam hal mengumpulkan tugas tepat waktu, bisa lebih mengingat rumusnya kembali dan memperhatikan guru ketika guru menyampaikan materi pada saat proses pembelajaran.

3. Komitmen, komunikasi dan kebersamaan dengan berbagai pihak perlu ditingkatkan lagi dalam hal bertanya supaya lebih jelas dan paham kembali materi yang sudah disampaikan di SD Negeri KarangTempel Semarang.

\section{Daftar Pustaka}

Aminah dan kiki riska ayu kurniawati. 2018. "analisis kesulitan siswa dalam menyelesaikan soal cerita matematika topik pecahan ditinjau dari gender”. jurnal teori dan aplikasi matematika, vol. 2 no. 2 , hal. 118-122.

Darjiani, Ni Nym. Yuni, I Gd. Meter dan I Gst. Agung Oka Negara. (2015). “analisis kesulitan-kesulitan belajar matematika siswa kelas $\mathrm{v}$ dalam implementasi kurikulum 2013di sd piloting sekabupaten gianyar tahun pelajaran 2014/2015”. Jurusan PGSD Volume: 3 No: 1 .

Ehan.https://www.google.com/url?sa=t\&sourc e=web\&rct=j\&url=http://file.upi.eu/dir ektori/fip/jur._pend._luar_biasa/195707 121984032ehan/kesulitan_belajar__ma tematika.pdf\&ved=2ahukewiwn6hioqx lahwmbiskhbjjcfmqfjabegqidrai\&usg= aovvaw3x93ozuybrq0gu6ina8hjg.

(diakses pada tanggal 14 Oktober 2019).

Irfan, Ade, Dwi Juniati dan Agung Lukito. (2018). "Profil Pemecahan Masalah Pecahan Siswa Sdberdasarkan 
Adversity Quotient”. Jurnal Program

Studi Pendidikan Matematika, Volume

4, No. 2.

Kodariyati, Laila dan Budi Astuti. (2016).

"Pengaruh Model Pbl Terhadap

Kemampuan Komunikasi Dan

Pemecahan Masalah Matematika Siswa

Kelas V Sd". Jurnal Prima Edukasia,

Volume 4, Nomor 1, (93 - 106).

Mufarizuddin. (2018). “Analisis Kesulitan

Pembelajaran Matematika Siswa Kelas

V Sd Negeri 012 Bangkinang Kota”.

Journal On Education, Volume 1, No. 1, 40-47.

nursalam. (2016). “diagnostik kesulitan

belajar matematika: studi pada siswa $\mathrm{sd} / \mathrm{mi}$ di kota makassar". lentera pendidikan, vol. 19 no. 1, 1-15.

Rostika, Deti dan Herni Junita. (2017). Unaenah, Een dan Muhammad Syarif "Peningkatan Kemampuan Pemecahan Masalah Siswa Sd Dalam Pembelajaran Matematika Dengan Model Diskursus Multy Representation (DMR)". Jurnal Pendidikan Dasar, Vol. 9. No.1, Hal $35-46$

Ruhyana. (2016). “Analisis Kesulitan Siswa Dalam Pemecahan 4 Masalah Matematika“. Jurnal Computech \& Bisnis, Vol. 10, No 2, 106-118.

Sholihah, Silfi Zainatu dan Ekasatya Aldila Afriansyah. (2017). "analisis kesulitan siswa dalam proses pemecahan masalah geometri berdasarkan tahapan berpikir van hiele". jurnal "mosharafa", volume 6 , nomor 2 .

Sugiyono. (2008). Metode Penelitian Kuantitatif. kualitatif dan $R \& D$. Bandung: Alfabeta.

Sumantri, M. S., \& Rachmadtullah, R. (2016). The effect of learning media and self regulation to elementary students' history learning outcome. Advanced Science Letters, 22(12), 4104-4108. https://doi.org/10.1166/asl.2016.8140

Tambunan, H., \& Napitupulu, E. (2016). Effectiveness of Interactive Multimedia Based Learning Model in Engineering Mechanics. International Education Studies, 9(10), 155-162. https://doi.org/10.5539/ies.v9n10p155 Sumantri. (2019). "analisis pemahaman konsep matematis siswa kelas 5 sekolah dasar pada materi pecahan. Jurnal Basicedu, Volume 3 Nomor 1, Halaman 106-111.

Untari, Erny. (2013). "Diagnosis Kesulitan Belajar Pokok Bahasan Pecahan Pada Siswa Kelas V Sekolah Dasar". Jurnal Ilmiah STKIP PGRI Ngawi, Vol.13 No. 1

Vaughan, T. (2011). Multimedia Making it work;8th Edition. New York: McGrawHill. 
Waskitoningtyas, rahayu sri. (2016). "analisis kesulitan belajar matematika siswa kelas v sekolah dasar kota balikpapan pada materi satuan waktu tahun ajaran 2015/2016". jurnal ilmiah pendidikan matematika, vol. 5 no. 1, hlm 24-32.

Waskitoningtyas, rahayu sri. "analisis kesulitan belajar matematika siswa kelas v sekolah dasar kota balikpapan pada materi satuan waktu tahun ajaran 2015/2016". jurnal ilmiah pendidikan matematika, vol. 5 no. 1, hlm 24-32.

Widjajant, Djamilah Bondan. (2009).

"Kemampuan Pemecahan Masalah Matematis Mahasiswa Calon Guru Matematika: Apa Dan Bagaimana Mengembangkannya”. Jurusan Pendidikan Matematika FMIPA UNY, 5 Desember 2009.
Winarno, S., Muthu, K. S., \& Ling, L. S. (2018). Impacts of m-DPBL Approach towards Computer Networks Teaching and Learning Process. International Journal of Emerging Technologies in Learning (iJET), 13(3), 207. https://doi.org/10.3991/ijet.v13i03.7944

Xia, C. (2018). Multimedia Teaching Platform Construction Based on Flash Interaction Technology for Gymnastics. International Journal of Emerging Technologies in Learning (iJET), 13(5), 224.

https://doi.org/10.3991/ijet.v13i05.84

Yeni, ety mukhlesi. (2015). "kesulitan belajar matematika di sekolah dasar". jupendas, vol. 2 , no. 2 